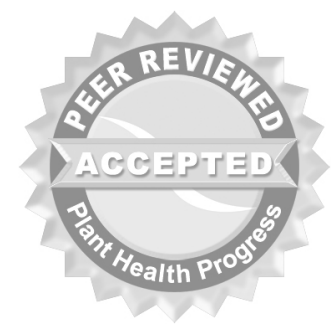

\title{
Field and Growth Chamber Inoculations Demonstrate Persea indica as a Newly Recognized Host for the Laurel Wilt Pathogen, Raffaelea laurciola
}

\author{
Marc A. Hughes, Department of Plant Pathology, University of \\ Florida, Gainesville, FL 32611; Gurpreet Brar, Department of \\ Entomology and Nematology, University of Florida, Gainesville, FL \\ 32611; Randy C. Ploetz, Department of Plant Pathology, Tropical \\ Research and Education Center, University of Florida, Homestead, FL \\ 33031; and Jason A. Smith, School of Forest Resources and \\ Conservation, University of Florida, Gainesville, FL 32611
}

Corresponding author: Marc A. Hughes. plantdochughes@gmail.com

Hughes, M. A., Brar, G., Ploetz, R. C., and Smith, J. A. 2013. Field and growth chamber inoculations demonstrate Persea indica as a newly recognized host for the laurel wilt pathogen, Raffaelea laurciola. Online. Plant Health Progress doi:10.1094/PHP-2013-081402-BR.

Laurel wilt, caused by the fungus Raffaelea lauricola, is a vascular disease of native and exotic trees in the Lauraceae in the USA (2). Recently, a study was conducted to investigate the attractiveness of Persea species to the laurel wilt vector, Xyleborus glabratus (redbay ambrosia beetle) (3). Hung bolts of the tree species $P$. indica were shown to be as or more attractive to $X$. glabratus than Persea borbonia (redbay), its primary host in the USA (3). In order to assess the susceptibility of $P$. indica to the laurel wilt fungus, field and growth chamber experiments were conducted. In May 2010, 12 trees of $P$. indica were planted at the University of Florida Plant Sciences Research and Education Unit in Citra, FL, and 10 were inoculated with $1.0 \times 10^{5}$ conidia of $R$. lauricola isolate RL4 (CBS 127349; GenBank accession no. HM446155) as described previously (4), with two trees serving as water-inoculated controls. After 6 weeks, all inoculated plants displayed symptoms of laurel wilt similar to those that develop on Persea americana (avocado), including wilt, defoliation, leaf necrosis, shriveling of small branches, and brown/black discoloration of sapwood. $R$. lauricola was consistently isolated from symptomatic sapwood $(2,4)$.

In March 2012, six containerized seedlings of $P$. indica, two of Persea palustris (swamp bay), a preferred host of $X$. glabratus and $R$. lauricola, and a Quercus alba (white oak) non-host control were placed in a growth chamber $\left(25^{\circ} \mathrm{C}, 12: 12\right.$ diurnal light). On all plants, bark was scored with a 3-mm corkborer, and to a single $P$. indica and $P$. palustris plant 3 empty gelatin capsules were attached to the lower stem (mock-inoculated controls). On the remaining $P$. indica plants and one each of $P$. palustris and the $Q$. alba, a single female of $X$. glabratus (reared from an infected redbay $\log$ ) within an individual gelatin capsule with ventilation holes was affixed to the lower stem, with 3 capsules/beetles per plant. After $48 \mathrm{~h}$, frass was visible and all beetles had successfully bored into the challenged plants of $P$. indica and $P$. palustris, whereas no boring activity or frass was visible on the $Q$. alba and mockinoculated controls (Fig. 1). After 8 weeks, all X. glabratus-challenged plants of $P$. indica and $P$. palustris displayed laurel wilt symptoms, while the control plants remained healthy. Typical colonies of $R$. lauricola were isolated from four of the five plants of $P$. indica and the $P$. palustris. Total genomic DNA was extracted from a single spore isolate (PL1529) recovered from a symptomatic $P$. indica, and a partial ribosomal small sub-unit fragment was amplified and sequenced with primers NS1 and NS4 (5). A BLASTn search showed, complete homology with multiple $R$. lauricola GenBank accessions, including RL4 (100\% 
similarity, and a total score of 1796). The sequence was deposited in GenBank under the accession $\mathrm{KC}_{333878 .}$

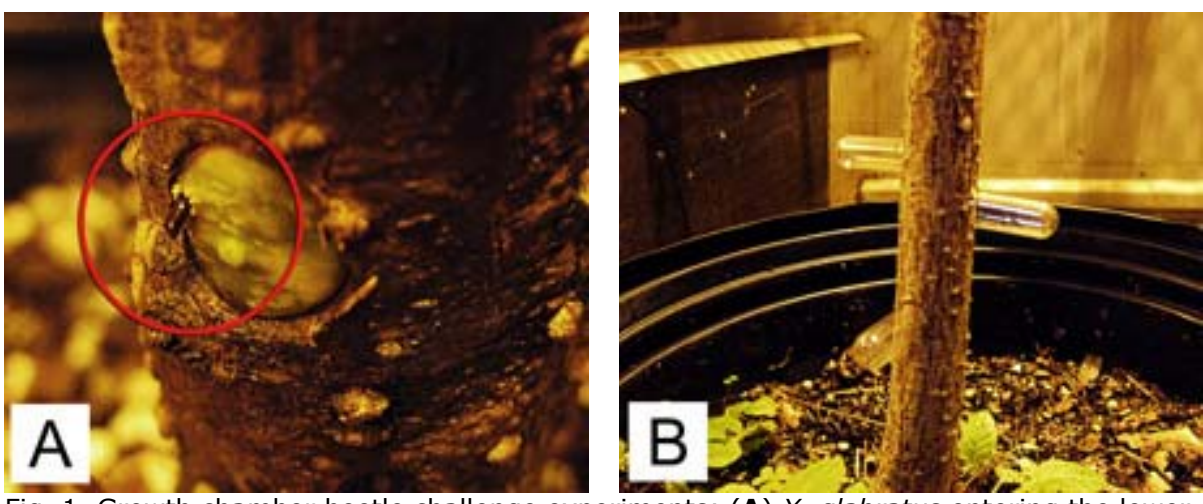

Fig. 1. Growth chamber beetle challenge experiments: (A) X. glabratus entering the lower stem of $P$. indica; (B) $P$. palustris mock-inoculated control depicting placement of gelatin capsules onto host.

Persea indica is an ancient member of the Lauraceae, endemic to Macaronesia. This species is a dominant member of the laurel forests (laurisilva) in the Madeira and Canary Islands, and an ornamental in the Mediterranean climates of the USA and Spain (1). The knowledge that $P$. indica wood is attractive to the vector and the above experiments demonstrating pathogenicity indicates that monitoring efforts must consider this species as a potential host and reservoir for the pathogen and vector. The introduction of laurel wilt in areas where $P$. indica is native may prove destructive to the environmentally significant laurisilva forests of Macaronesia. In addition, $P$. indica trees in proximity to the $P$. americana (avocado) production areas of California and Spain may act as a host-bridge, bringing laurel wilt to these areas that have yet to be affected by the disease.

\section{Literature Cited}

1. Campos, P. S., and Pais, M. S. S. 1996. In vitro micropropagation of the Macaronesian evergreen tree Persea indica (L.) K. Spreng. In Vitro Cell. Dev. Biol.: Plant 32:184-189.

2. Harrington, T. C., Fraedrich, S. W., and Aghayeva, D. N. 2008. Raffaelea lauricola: A new ambrosia beetle symbiont and pathogen on the Lauraceae. Mycotaxon 104:399-404.

3. Pena, J. E., Carrillo, D., Duncan, R. E., Capinera, J. L., Brar, G., Mclean, S., Arpaia, M. L., Focht, E., Smith, J. A., Hughes, M., and Kendra, P. E. 2012. Susceptibility of Persea spp. and other Lauraceae to attack by redbay ambrosia beetle, Xyleborus glabratus (Coleoptera: Curculionidae: Scolytinae). Fla. Entomol. 95:783-787.

4. Ploetz, R. C., Perez-Martınez, J. M., Smith, J. A., Hughes, M., Dreaden, T. J., Inch, S. A., and Fu, Y. 2012. Responses of avocado to laurel wilt, caused by Raffaelea lauricola. Plant Pathol. 61:801-808.

5. White, T. J., Bruns, T., Lee, S., and Taylor, J. 1990. Amplification and direct sequencing of fungal ribosomal RNA genes for phylogenetics. Pages 315-322 in: PCR Protocols: A Guide to Methods and Applications. M. A. Innis, D. H. Gelfand, J. J. Sninsky, and T. J. White, eds. Academic Press, San Diego, CA. 